Duško Petrović

\section{Izbjeglištvo u suvremenom svijetu: od političkoteorijskih utemeljenja do biopolitičkih ishoda}

Zagreb: Naklada Ljevak, 2016, 440 str.

DOI: https://doi.org/10.11567/met.34.2.4

Fenomen izbjeglištva, prisutan $\mathrm{u}$ današnjemu javnome, medijskom i znanstvenom diskursu, svejednako je prihvaćan, osporavan i sumnjičen u diskurzivnim i upravljačkim praksama državnih aparata i međunarodnih proponenata humanitarne i biopolitičke moći. Knjiga Duška Petrovića, docenta na Odsjeku za etnologiju i kulturnu antropologiju Filozofskog fakulteta Sveučilišta u Zagrebu, objavljena je neposredno nakon nečega što se politički konotirano naziva »izbjegličkom krizom«, premda je prije svega riječ o krizi humanosti i europskih vrijednosti, a posebice solidarnosti. No ona je itekako aktualna i danas kao i nakon što je prestao postojati Balkanski humanitarni koridor, kojim su od ljeta 2015. do proljeća 2016. u potrazi za sigurnim, stabilnim i boljim životom prošle stotine tisuća izbjeglica. Knjiga je stoga ne samo vrijedno teorijsko djelo nego mjestimice i dokument vremena jer je zabilježila događaje na dionici njihova puta $\mathrm{u}$ tipu državnoga regulatornoga humanitarno-sigurnosnog mehanizma koji su Hameršak i Pleše nazvale »mobilnom detencijom «. Unutar tog mehanizma u strogo kontroliranim uvjetima pograničnih područja i prihvatnotranzitnih centara u Opatovcu i Slavonskom Brodu, u posvema ograničavajućim uvjetima tranzita, svega je nekolicina prisilnih migranata zatražila izbjeglički status u Hrvatskoj. Pojedini autori, poput Hess i Kaspareka, sugeriraju kako smo u tom vremenu svjedočili destabilizaciji pa ponovnoj restabilizaciji graničnih režima Schengenskog sustava. Reperkusije te epizode itekako osjećamo i uočavamo i danas, kada mnogi u potrazi za sigurnošću i boljim životom bivaju sistemski ograničeni i uskraćeni tako da ih se svakodnevno nasilno zaustavlja, odvraća, zatvara i prisilno vraća nazad, pred samim granicama Schengena. Na korak do sanjane i priželjkivane Europske unije, bez jasne su vizije tko ih i što tamo čeka - vjerojatno ne mnogo dobroga, s obzirom na sve rigidnije i restriktivnije azilne, migracijske i integracijske politike i ograničenja prava na pristup teritoriju i postupku traženja zaštite.

Autor $\mathrm{u}$ »Uvodu« ocrtava smjer svog opisa i analize stanja u kojem se Europa i svijet danas nalaze s obzirom na aktualnost izbjegličke problematike. Njegov analitički smjer s jedne stane čini »sekuritizacija« (sigurnosnizacija), a s druge imperativ humanitarnosti u suvremenim politikama azila. Namjera mu je opisati genealoški nastanak globalnoga izbjegličkog režima kroz dijakronijski kritički pregled izbjeglištva kao povijesnoga i politički bremenitog fenomena. Dodatno, u sveobuhvatnijoj sinkronijskoj perspektivi autor pruža i uvide u načine političko-ontološkog (su)kreiranja izbjegličkog režima, kao i onih suvremenih nacionalnih sustava azila koji su shvaćeni kao devijacije tog režima, ali su zapravo njegova logična posljedica. Strukturna analiza temeljnih postavki globalnoga izbjegličkog režima u svijetu počiva na raščlambi 
onoga što Petrović smatra njegovim ontološkim temeljem, a što nalazi inherentnim svojstvom doba kasne moderne: riječ je o politizaciji samoga biološkog života i prakticiranju biopolitike koja ima presudan, dominantan i hegemonijski utjecaj na razvoj azilnih, migracijskih, državljanskih i inih politika. Početkom 20. stoljeća iskustva ratnih sukoba, nestanka velikih carstava, prekrajanja granica i raseljavanja dovela su do toga da su najednom mnogi ostali bez prava na dom, sigurnost, jezik, ime i identitet. Svijet se bio našao pred temeljnom krizom: nacijedržave ne samo da nisu mogle osigurati život i zaštitu temeljnih ljudskih/ građanskih prava nego i postaju glavnim akterima njihova kršenja. Autor nadalje objašnjava strukturu monografije te precizira metodološke postupke koji su kombinacija kritičkog pregleda filozofske, političke, sociološke i kulturnoantropološke literature na ovu temu te (auto)refleksivnih razmišljanja o vlastitome izbjegličkom iskustvu i uvida pri terenskim posjetima prihvatno-tranzitnim centrima, a zapravo kolektivnim kampovima za prihvat, detenciju i daljnji organizirani tranzit kroz Hrvatsku.

U prvoj cjelini »Izbjeglice, apatridi, azilanti i moderna politika« autor analizira nacionalne tipove političke suverenosti koji rezultiraju upravo podvajanjem politika (sigurnosno-humanitarnih), ali i stavovskih odrednica naspram »Drugoga « kao tražitelja zaštite, izbjeglica, migranata, a i općega tipa »stranca «. $S$ jedne strane, razvoj međunarodnog sustava izbjegličke zaštite podrazumijeva humanitarizaciju pitanja izbjeglištva, njegovanje politika sućuti i karitativnosti, što nerijetko skreće u pasiviziranje i desu- bjektiviziranje »mase « koja treba »pomoć«, ali ne dobiva glas i politička prava. S druge strane, "sekuritizacija politika izbjeglištva podrazumijeva da se one vezuju uz prakse kontrole i nadzora, snižavanja prava i standarda zaštite, te »kriznog upravljanja « fenomenom izbjeglištva kroz prizmu »izvanrednog stanja« koje iziskuje »izvanredne mjere«. Kao kulturni antropolog, jakoga filozofskog senzibiliteta i pristupa, autor kritički propituje ulogu uopćenoga, apstraktnog državnog aparata na razvoj i provođenje birokratiziranih i opresivnih biopolitika za one koji (p)ostaju bez prava $\mathrm{i} »$ bez mjesta na zemlji«.

Druga, najopsežnija i središnja cjelina knjige »Razumijevanje biopolitike« donosi analizu općih teorijskih koncepata, počevši od samog Foucaultova pojma biopolitike, (bio)moći, ideologije, države, suverenosti, »života po sebi«i drugih, koje autor tematizira i na kojima gradi daljnju argumentaciju i kritičku analizu. Posebno se vrijednim može izdvojiti njegov pokušaj razumijevanja dviju bitnih značajki modernih društava, privilegiranja rada i proizvodnje, koje postaju temeljem instrumentaliziranja moći nad prirodom i nad ljudima. Time se objašnjava kako se mehanizmi biomoći pretvaraju u ekstenziju sustava u kojem se upravljanje »tijelima« $\mathrm{i} »$ masom « izbjeglica prokazuje kao produžena ruka opresivnoga, hegemonijskog i skriveno totalitarnog režima upravljanja međunarodnim migracijama i fenomenom izbjeglištva. Globalna nejednakost koja uzrokuje ratove, sukobe oko resursa i socioekonomsku deprivaciju te dovodi do prisilnog raseljavanja brojnih ugroženih tako postaje samotinjajući mehanizam ruke 
koja nastoji »upravljati i pomagati«, a zapravo iskorištavati, kontrolirati, kažnjavati te iskazivati milosrđe.

U trećoj cjelini »Fenomen izbjeglištva i biopolitika« autor analizira načine na koje se uspostavljaju javne politike i institucionalne prakse, kao i pravni, medijski i javni diskursi i prikazi o izbjeglicama. Na temelju postojeće društveno-humanističke literature o fenomenu izbjeglištva analizira službene dokumente: izvještaje, zakone i pravilnike koji u hrvatskom kontekstu uređuju ovo područje. Dodatno nam podastire razmišljanja na temelju »autoetnografije sjećanja « na osobno izbjegličko iskustvo te uvide koje je stekao kroz terensko istraživanje $\mathrm{u}$ prihvatno-tranzitnom centru. Kraj ove cjeline donosi vrijedna svjedočenja i iskustva autora, koji je dvaput boravio u tranzitnim kampovima, u Slavonskom Brodu i Šidu, te je uz sudjelujuće promatranje razgovarao s mnogim dionicima sustava, djelatnicima kampova te izbjeglicama i volonterima. Uočenu i analiziranu strategiju upravljanja tim centrima naziva »sigurnosnim humanitarizmom« i sažima: »Zaključno se može reći da je izgradnjom centra u Slavonskom Brodu bio stvoren biopolitički humanitarni prostor na teritoriju nacionalne države čija je glavna svrha poticanje i kontroliranje toka ljudi uz primjenu kontroliranog nasilja te brigu o njihovim tijelima i biološkom životu« (str. 415).

Knjiga je vrijedan interdisciplinarni doprinos shvaćanju fenomena izbjeglištva $u$ europskome i međunarodnom kontekstu, u kojem politička filozofija čini glavni fundus i teorijsku os oko koje se sakupljaju autorovi kulturnoantropološki i sociološki uvidi i razmišljanja. Kao takva ona je vrijed- na polazišna točka za daljnja bavljenja ovom temom s akademske razine, ali i s one praktične, pri čemu bi svaki kreator i provoditelj azilnih, migracijskih i integracijskih politika i praksi mogao pronaći sažeta kritička čitanja povijesnog razvoja, nastanka i održavanja politika koje nastoje upravljati ovim fenomenom, premda bismo i to »upravljanje« mogli shvatiti prije svega kao mehanizam kontrole. Stil knjige mjestimice je hermetičan, što proizlazi iz autorove političkofilozofske provenijencije. Otvaranje novih teorijskih, konceptualnih i praktičnih pitanja za moguće alternativne pristupe samo je naznačeno. Ti bi pristupi potencijalno vodili dekonstruiranju i repozicioniranju danas prevladavajućih politika, praksi i diskursa te stvarali proaktivnije, solidarnije, egalitarnije i emancipiranije sagledavanje čitave problematike. Ipak, i bez toga knjiga donosi pregledno i interdisciplinarno teorijsko promišljanje i kritičku analizu fenomena raseljenosti, izbjeglištva i biopolitika, a ima i znatan potencijal za daljnje senzibiliziranje studenata, stručne i šire javnosti za ovu tematiku. Kao takva zasigurno će naći svoju publiku, a, nadam se, i svoje nastavljače, jer će iz godine u godinu tema izbjeglištva bivati sve vidljivijom i sve značajnijom i u hrvatskom kontekstu.

Drago Župarić-Iljić Odsjek za sociologiju, Filozofski fakultet Sveučilišta u Zagrebu, Zagreb 
